\title{
Evaluasi Pertumbuhan Sambungan Eucalyptus pellita F. Muell dengan Teknik Veneer Grafting
}

(Growth Evaluation of Veneer Grafting Method for Eucalyptus pellita F. Muell Clone)

\section{Oleh:}

Hamdan Adma Adinugraha ${ }^{1}$, Trisya Ranti Fani ${ }^{2}$ dan Yayan Hadiyan ${ }^{3}$

${ }^{1,3)}$ Peneliti pada Balai Besar Penelitian Bioteknologi dan Pemuliaan Tanaman Hutan

${ }^{2)}$ Fakultas Kehutanan Universitas Gadjah Mada

Email : hamdan_adma@yahoo.co.id

\begin{abstract}
ABSTRAK
Eucalyptus pellita F. Muell adalah salah satu jenis tanaman potensial sebagai bahan pulp di Indonesia. Aktivitas pemuliaan telah dilakukan untuk mendapatkan tanaman ekaliptus yang memiliki produktivitas tinggi melalui seleksi individu-individu bergenetik unggul. Teknik perbanyakan menjadi hal penting dalam upaya pengembangbiakan sifat unggul tesebut. Veneer grafting adalah salah satu teknik perbanyakan yang direkomendasikan. Tujuan penelitian ini adalah mengetahui kompatibilitas sambungan beberapa klon dari pohon plus Eucalyptus pellita. Penelitian ini menggunakan design Rancangan Acak Lengkap dengan 36 families Eucalyptus pellita and 6 famili hibrid (E. pellita $\mathrm{x} E$. brassiana) sebagai perlakuan, dan 4 ulangan. Hasil pengamatan menunjukan bahwa klon $E$. pellita berpengaruh nyata terhadap persen hidup, jumlah tunas, pertumbuhan panjang tunas dan diameter tunas dari klon yang diamati. Persentase hidup klon berkisar antara $0-100 \%$. Jumlah tunas berkisar 1-3 batang. Rata-rata panjang tunas berkisar 0,17 cm - 17,82 cm. Diamater tunas berkisar 0,10 mm - 2,27 mm. Klon no. 19 dari Keru To Nata WP, Papua New Guinea mempu mencapai persen hidup $100 \%$ hingga akhir pengamatan. Klon no. 33 memiliki pertumbuhan terbaik untuk jumlah tinas, diameter tunas dan dan panjang tunas.
\end{abstract}

Kata kunci : Eucaltyptus pellita, pertumbuhan, teknik grafting veneer

\section{ABSTRACT}

Eucalyptus pellita F. Muell is one of the promising species for pulp production in Indonesia. Tree breeding activities of this species have been developed to investigate a high productivity of Eucalypt through the selection of genetically improved individual trees. Vegetative propagation technique is an important tool needed to multiple the trees. Veneer Grafting is one of the recommended propagation techniques. The objective of the research is to study the compatibility of several E. Pellita clones that are produced from plus trees. Implemented by Completely Randomized Design (CRD), the research was used $36 E$. pellita families and 6 hibryds of E. pellita $\mathrm{x}$ E. brassiana as the treatment with 4 replications. The result showed that the clone of E. pellita was significantly different effecting growth variation of clone adaptability, shoot number, shoot length, and shoot 
diameter. Clone adaptability was range from 0 - 100\%. Shoot number was around 1-3 stems. Shoot length was range $0.17 \mathrm{~cm}-17.82 \mathrm{~cm}$ and the shoot diameter was $0.10 \mathrm{~mm}-$ $2.27 \mathrm{~mm}$ in range. The clone (number 19) from Keru To Nata WP Papua New Guinea was invented as the best in adaptability (100\%) during the observation period, while clone (number 33) was the best growth performance in shoot number, shoot diameter and shoot length.

Key words : Growth, Eucalyptus pellita, veneer grafting

\section{PENDAHULUAN}

Eucayiptus pellita adalah salah satu jenis penghasil kayu untuk bahan baku pulp di Indonesia. Jenis ini merupakan tanaman cepat tumbuh yang telah dikembangkan secara luas dalam bentuk hutan tanaman industri (HTI) terutama di pulau Sumatera dan Kalimantan. Namun demikian dilaporkan jenis ini merupakan bahan kayu bakar dan arang yang baik, menghasilkan minyak esensial untuk bahan obat dan parfum serta menghasilkan madu melalui budidaya lebah madu/apiculture (Orwa et al., 2009; Dombro, 2010; Proenza et al., 2013). Meski memiliki cakupan tempat tumbuh yang lebar, tetapi kebanyakan ekaliptus tidak tahan suhu dingin. Siahaan (2010) melaporkan bahwa menurut Rauf (2009) dalam tanaman Ekaliptus tumbuh dengan baik pada suhu rata-rata per tahun $20^{0}$ hingga $32^{0}$ Celcius dan menurut Latifah (2004) Sebaran alami Ekaliptus berada di sebelah Timur garis Wallace, mulai dari $7^{\circ}$, LU sampai 4339' LS meliputi Australia, New Britania, Papua dan Tazmania. Beberapa spesies juga ditemukan di Kepulauan Indonesia yaitu di Irian Jaya (papua), Sulawesi, Nusa Tenggara Timur dan Timor -Timur.

Kegiatan pemuliaan tanaman ini telah dilakukan oleh banyak pihak untuk mendapatkan tanaman yang memiliki produktivitas tinggi melalui kegiatan seleksi individu yang bergenetik unggul. Menurut Leksono (2001), jenis ini memiliki pertumbuhan yang baik pada sifat bentuk batang, kecepatan tumbuh dan kualitas kayu, serta kemampuan bertunas tinggi yang sangat diperlukan untuk pengembangan hutan tanaman industri/HTI jenis ini. Dalam rangka penyediaan benih unggul jenis ini, telah dibangun beberapa plot uji keturunan seperti di Wonogiri (Jawa Tengah), Lipat Kain (Riau) dan Pelaihari (Kalimantan) yang kemudian dikonversi menjadi kebun benih. Pohon plus yang terpilih kemudian dijadikan bahan untuk pembangunan uji keturunan F2 dan sebagai sumber benih dalam pembangunan HTI (Leksono dan Setyaji, 2010). 
Dalam upaya perbanyakan individu-individu terseleksi (plus tress) tersebut telah banyak dilakukan ujicoba perbanyakan tanaman secara vegetatif dengan teknik sambungan, stek pucuk dan kultur jaringan (Adinugraha dan Sunarti, 2004; Adinugraha et al., 2007; Herdyantara, 2010). Penerapan teknik permbiakan vegetatif bermanfaat untuk pembangunan bank klon, kebun persilangan, uji klon (Sachs, 1988; Khan, 1995; Kulkarni, 2002; Sunarti, 2012). Salah satu teknik sambungan yang dapat dilakukan yaitu veneer grafting. Dari hasil penelitian awal diperoleh keberhasilan hidup sambungan mencapai 73,33-80,00\% dengan entries/scion dari tajuk maupun dari trubusan pada batang yang dilukai (Adinugraha dan Sunarti, 2004). Teknik ini relatif mudah dilakukan dan dapat diperoleh bibit dalam jumlah cukup banyak. Untuk mengetahui kemampuan hidup (kompatibilitas) sambungan klon-klon E. pellita dari kebun benih F1 di Wonogiri maka perlu dilakukan pengujian penerapan teknik veneer grafting ini, sehingga diharapkan akan diperoleh informasi yang sangat bermanfaat untuk pengembangan jenis ini.

\section{BAHAN DAN METODE PENELITIAN}

\section{Lokasi dan waktu Penelitian}

Penelitian dilakukan di Persemaian Balai Besar Penelitian Bioteknologi dan Pemuliaan Tanaman Hutan di Sleman, Daerah Istimewa Yogyakarta. Lokasi tersebut terletak pada ketinggian $287 \mathrm{~m}$ dpl, memiliki tipe iklim B menurut Schmidt dan ferguson, curah hujan rata-rata $1.878 \mathrm{~mm} /$ tahun, suhu rata-rata $27^{\circ} \mathrm{C}$ dan kelembaban relatif $73 \%$. Penelitian ini merupakan bagian dari kegiatan penelitian Pengembangan Populasi Perbanyakan Jenis Eucalyptus pellita yang dilakukan sampai dengan tahun 2007 dalam rangka pengadaan bibit untuk pembangunan kebun benih klon jenis tersebut.

\section{Alat dan Bahan Penelitian}

Alat-alat yang digunakan dalam penelitian ini meliputi pisau grafting atau cutter, gunting stek, gunting galah, ice box dan alat tulis, sedangkan bahan penelitian terdiri dari entries/scion dari beberapa pohon plus Eucalyptus pellita di kebun benih F1 di Wonogiri Jawa Tengah, rootstock berupa bibit Eucayiptus pellita yang telah berumur 5-6 bulan di persemaian, plastik pengikat bagian sambungan/parafilm, label dan plastik bening ukuran 1 kg. Adapun informasi pohon induk tanaman eukaliptus yang digunakan selengkapnya disajikan pada Lampiran 1. 


\section{Prosedur Penelitian}

1. Penyediaan bibit rootstock dan entries/scion dari pohon plus di kebun benih Bibit rootstock yang digunakan adalah bibit hasil penyemaian benih E. pellita di persemaian yang telah berumur sekitar 5-6 bulan dengan tinggi rata-rata $60-70 \mathrm{~cm}$ dan diameter batangnya berukuran rata-rata $1 \mathrm{~cm}$. Adapun pengambilan scion dilakukan dengan cara memanjat pohon plus dan memotong sebagian rantingnya. Setiap ranting digunting daun-daunnya dan dikelompokkan berdasarkan masingmasing pohon induknya. Setiap kelompok scion diikat dan diberi label sesuai dengan nomor pohon plus yang diambil. Setiap ikatan scion kemudian dibungkus dengan koran basah dan disusun dalam ice box untuk selanjutnya diangkut ke persemaian di Sleman, Yogyakarta.

\section{Proses pengerjaan veneer grafting}

a. Penyiapan root stock diiawali dengan memotong root stock secara melintang dengan gunting stek dan dihaluskan dengan pisau grafting. Salah satu sisi root stock disayat dengan lebar sayatan $0,5-0,7 \mathrm{~cm}$ dengan panjang sayatan $\pm 2 \mathrm{~cm}$ dengan tinggi root stock $20-25 \mathrm{~cm}$.

b. Penyiapan scion dilakukan dengan cara scion dipotong secara melintang dan membuang semua daunnya. Panjang scion 4-6 cm dengan jumlah mata tunas 2. Ukuran diameter pangkal scion $\geq 0,5 \mathrm{~cm}$. Salah satu sisinya di sayat tipis tidak melebihi lapisan kambium. Bagian ujung scion dipotong miring dengan arah berlawanan dengan bagian sayatan.

c. Penyambungan scion pada root stock sehingga bagian permukaan sayatan menempel erat pada salah satu tepi sayatan root stock. Sambungan diikat dengan parafilm sehingga kambiumnya dapat melekat erat. Ujung scion diolesi dengan pasta penutup grafting. Kemudian secion dibungkus dengan kantung plastik untuk mencegah evaporasi dan hentakan air hujan/air penyiraman. Setelah sambungan tumbuh, plastik sungkup dibuka secara bertaha untuk mencegah perubahan kondisi lingkungan secara mendadak yang dapat meneybabkan kelayuan bahkan kematian tunas.

3. Rancangan Penelitian

Penelitian ini didesign dengan Rancangan Acak Lengkap (RAL), perlakuan disusun secara tersarang (nested) menggunakan 42 famili pohon plus (36 famili Eucayiptus pellita dan 6 Famili yang diduga hibrid antara E. pellita dan E. brassiana) dengan 
ulangan sebanyak 4 kali untuk masing-masing klon, setiap ulangan terdiri dari 1 sampel bibit sehingga seluruhnya terdapat 168 bibit sambungan.

4. Pengamatan dan pengukuran

Keberhasilan teknik grafting veneer tersebut diukur melalui pengamatan parameter persen hidup, jumlah tunas, panjang tunas dan diameter tunas. Persen hidup sambungan dinilai dengan menggunakan sistem skoring sebagimana dikembangkan Moko et al., (2001) : Scion hidup (5), scion hidup dan baru muncul tunas (4), Scion asih segar belum tumbuh calon tunas (3), sebagian scion mulai membusuk (2) dan scion mati busuk/kering (1).

Adapun sifat-sifat pertumbuhan yang diamati untuk menilai keberhasilan sambungan meliputi 1) jumlah tunas yang dihitung sebagai total tunas yang tumbuh pada satu sambungan, 2) panjang tunas yang diukur mulai dari pangkal tunas sampai dengan ujung tunas menggunakan penggaris bersakala dan 3) diamater tunas diukur tepat pada pangkal tunas menggunakan kaliper. Pengukuran dilakukan secara periodik setiap minggu sekali selama 2 bulan.

\section{Analisis Data}

Data yang diperoleh dianalisis sesuai dengan model dan rancangan rancangan percobaan yang dipergunakan. Analisis data dilakukan dengan membuatan analisis varian (anova) dan dilanjutkan dengan Uji Duncan's Multiple Range Test (DMRT) untuk mengetahui klon terbaik berdasarkan rengkingnya dengan taraf uji 5\%. Model rancangan yang digunakan mengacu pada Satrosupadi (2000) :

$$
Y_{i j k}=\mu+T_{i}+B_{j(t i)}+\varepsilon_{i j k}
$$

Keterangan :

$\mathrm{Y}_{\mathrm{ijk}}=$ respon/nilai pengamatan;

$\mu=$ nilai tengah umum;

$\mathrm{T}_{\mathrm{i}}=$ pengaruh jenis ke-i;

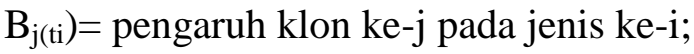

$\varepsilon_{\mathrm{ijk}}=$ error percobaan. 


\section{HASIL DAN PEMBAHASAN}

\section{Keberhasilan Hidup}

Persen hidup tanaman hasil sambungan merupakan indikator penting untuk mengukur keberhasilan teknik veneer grafting yang digunakan. Hasil pengamatan selama dua bulan di persemaian menunjukkan bahwa persen hidup 42 klon E. pellita tersebut bervariasi. Persen hidup klon berkisar dari $0 \%$ (tidak tumbuh sama sekali) sampai 100\% (tumbuh seluruhnya) dengan kisaran terbanyak diantara 25\%-75\% (Gambar 1). Persentase hidup sambungan terbaik (100\%) ditunjukkan oleh klon no. 19 yang berasal dari Keru To Nata WP, Papua New Guinea. Dari pengamatan diketahui pula bahwa terdapat 12 klon yang tidak tumbuh sama sekali sampai akhir pengamatan yaitu klon 2, 4, 5, 6, 8, 9, 12, 20, 22, 23, 24 , dan 29. Sedangkan sisanya menunjukkan keberhasilan tumbuh sambungan antara 25\%$75 \%$. Hasil tersebut menunjukkan adanya variasi kemampuan tumbuh sambungan dari 42 klon yang diuji. Secara umum keberhasilan tumbuh sambungan dipengaruhi oleh banyak factor antara lain musim, kesesuaian antar scion dan root stock, temperatur, kelembaban media, umur tanaman baik scion maupun bibit root stock, kontak antara scion dan root stock dan kegiatan pemeliharaan di persemaian (Kumar, 2011; Chipojola et al., 2013; Cholid et al., 2014).

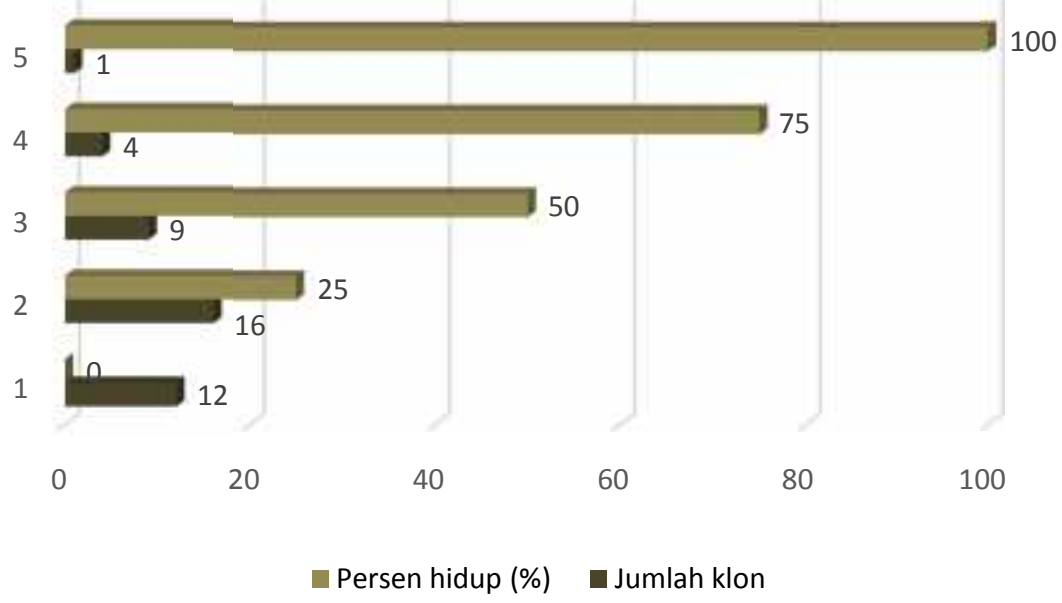

Gambar 1. Grafik persentase hidup sambungan E. pellita di persemaian 
Tabel 1. Hasil analisis varian persentase hidup klon hasil veneer grafting E. pellita

\begin{tabular}{|c|c|c|c|c|c|c|c|c|c|}
\hline \multirow[b]{2}{*}{$\begin{array}{l}\text { Sumber } \\
\text { Variasi }\end{array}$} & \multirow[b]{2}{*}{$\mathrm{db}$} & \multicolumn{8}{|c|}{ Rerata kuadrat } \\
\hline & & Persen hidup & F.hit & $\begin{array}{l}\text { Jumlah } \\
\text { tunas }\end{array}$ & F.hit & $\begin{array}{c}\text { Panjang } \\
\text { tunas }\end{array}$ & F.hit & $\begin{array}{c}\text { Diameter } \\
\text { tunas }\end{array}$ & F.hit \\
\hline Jenis & 1 & 264,88 & 0,95 & & 0,38 & & 0,43 & & \\
\hline Klon (jenis) : & 40 & $540,85 * *$ & 1,93 & $3,051 *$ & 1,48 & $87,3270 *$ & 1,37 & $1,2171 *$ & 1,56 \\
\hline Klon E. pellita & 5 & $551,06 * *$ & 1,68 & $3,187 *$ & 1,62 & $91,4968 *$ & 1,72 & $1,3032 *$ & 1.83 \\
\hline $\begin{array}{l}\text { Klon hibrid } \\
\text { Error }\end{array}$ & $\begin{array}{c}35 \\
126\end{array}$ & $\begin{array}{c}469,41 \mathrm{~ns} \\
280,03\end{array}$ & 1,97 & $\begin{array}{l}2,100 \mathrm{~ns} \\
2,067\end{array}$ & 0,8 & $\begin{array}{l}58,0887 \mathrm{~ns} \\
63,823\end{array}$ & 0,45 & $\begin{array}{l}0,6147 \mathrm{~ns} \\
0,7795\end{array}$ & 0,52 \\
\hline Total & 167 & & & & & & & & \\
\hline era & 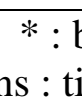 & $\begin{array}{l}\text { eda nya } \\
\text { berbed }\end{array}$ & da & ff $5 \%$ & & & & & \\
\hline
\end{tabular}

Tabel 1 di atas menunjukan bahwa variasi keberhasilan tumbuh sambungan dipengaruhi secara signifikan oleh klon E. pellita yang diuji pada semua sifat yang diamati, sedangkan klon hybrid tidak berpengaruh. Namun demikian terdapat faktor-faktor lain yang berpengaruh terhadap keberhasilan tumbuh sambungan E. pellita. Adanya penyimpanan scion yang selama pengambilan dari Wonogiri sampai pelaksanaan grafting yang membutuhkan waktu hingga 1 hari. Menurut Moko et al., (2001) lama penyimpanan scion berpengaruh terhadap persen hidup karena berhubungan dengan menurunnya kondisi fisiologis scion. Disisi lain, rendahnya keberhasilan grafting juga bisa disebabkan oleh kurang baiknya kualitas teknis sambungan, perbedaan vigoritas klon juga perbedaan waktu tumbuh tunas dari root stock yang lebih cepat daripada tunas dari scion. Posisi scion pada tajuk pohon induk juga dapat berpengaruh dan tipe scion yang digunakan juga dapat berpengaruh terhadap pertumbuhan sambungan (Hibert-Frey et al., 2011; Korkutal et al., 2011). Adanya serangan jamur pada bagian sambungan juga biasanya menjadi faktor penyebab yang paling banyak menyebabkan kegagalan tumbuh bibit sambungan (Rehab et al., 2013). Untuk menilai keberhasilan tumbuh sambungan masing-masing klon selanjutnya dilakukan uji DMRT terhadap total skor selama 2 bulan pengamatan yang hasilnya disajikan pada Tabel 2. 
Vol. 4 No.3, Juli 20I6 (124-138)

Tabel 2. Hasil uji DMRT skor persentase hidup klon hasil veneer grafting E. Peliita

\begin{tabular}{ccclcccr}
\hline $\begin{array}{c}\text { No } \\
\text { Urut }\end{array}$ & $\begin{array}{c}\text { Nomor } \\
\text { Famili }\end{array}$ & $\begin{array}{c}\text { Skor Persen } \\
\text { Hidup }\end{array}$ & DMRT & $\begin{array}{c}\text { No } \\
\text { Urut }\end{array}$ & $\begin{array}{c}\text { Nomor } \\
\text { Famili }\end{array}$ & $\begin{array}{c}\text { Skor Persen } \\
\text { Hidup }\end{array}$ & DMRT \\
\hline 1 & 19. & 36,50 & a & 19 & 31. & 23,75 & abcdef \\
2 & 35. & 35,25 & ab & 20 & 16. & 22,75 & abcdef \\
3 & 33. & 34,75 & ab & 21 & 24. & 21,75 & abcdef \\
4 & 26. & 32,50 & abc & 22 & 25. & 21,00 & abcdef \\
5 & 13. & 32,00 & abcd & 23 & 15. & 20,00 & abcdef \\
6 & 32. & 31,00 & abcde & 24 & 23. & 18,75 & bcdef \\
7 & 10. & 27,50 & abcdef & 25 & 17. & 17,75 & cdef \\
8 & 34. & 27,25 & abcdef & 26 & 2. & 17,00 & def \\
9 & 18. & 26,25 & abcdef & 27 & 22. & 15,75 & ef \\
10 & 1. & 25,25 & abcdef & 28 & 12. & 14,75 & ef \\
11 & 3. & 25,25 & abcdef & 29 & 4. & 14,25 & ef \\
12 & 7. & 25,00 & abcdef & 30 & 6. & 14,00 & ef \\
13 & 9 & 25,00 & abcdef & 31 & 8 & 13,75 & ef \\
14 & 14. & 25,00 & abcdef & 32 & 5. & 12,50 & f \\
15 & 21. & 25,00 & abcdef & 33 & 20. & 12,00 & f \\
16 & 28. & 25,00 & abcdef & 34 & 29. & 12,00 & f \\
17 & 30. & 25,00 & abcdef & 35 & 11. & - & \\
18 & 36. & 25,00 & abcdef & 36 & 27. & - & \\
\hline
\end{tabular}

\section{Pertumbuhan Tunas}

Keberhasilan tumbuh sambungan umumnya melalui tiga tahapan yaitu pembentukan kalus, penyatuan cambium dan penyatuan jaruingan pengangkut (Mahunu et al., 2013). Selanjutnya dengan adanya penyatuan jaringan pengangkut maka proses pengangkutan air dan unsure hara dapat berjalan dengan baik dan memacu pertumbuhan sambungan pada bagian apikal/tunas dan akar (Ballesta et al., 2010). Hasil pengamatan jumlah tunas rerata jumlah tunas dari klon-klon E. pellita yaitu 0,25 - 3 tunas dengan pertunasan terbanyak ditunjukkan oleh klon no. 33 dan 19, sedangkan terendah pada klon no. 7, 10, 14 dan 28 (Tabel 3). Perbedaan pertumbuhan jumlah tunas dipengaruhi secara nyata oleh faktor klonklon E. pellita yang diuji, sedangkan klon hibrid tidak berpengaruh secara nyata. Untuk selanjutnya pertumbuhan tunas dapat dipengaruhi kondisi lingkungannya, seperti ketersediaan unsur hara, oksigen, suhu, kelembaban, cahaya matahari (Lavender, 1984) dan tingkat keberhasilan penyatuan rootstock dan scion Baswarsianti et al., (1995). 
Vol. 4 No.3, Juli 20I6 (I24-138)

Tabel 3. Rerata jumlah tunas dan hasil uji DMRT klon veneer grafting E. pellita

\begin{tabular}{cccccccc}
\hline No urut & $\begin{array}{c}\text { Nomor } \\
\text { famili }\end{array}$ & $\begin{array}{c}\text { Jumlah } \\
\text { Tunas }\end{array}$ & DMRT & No urut & $\begin{array}{c}\text { Nomor } \\
\text { famili }\end{array}$ & $\begin{array}{c}\text { Jumlah } \\
\text { Tunas }\end{array}$ & DMRT \\
\hline 1 & 33. & 3,00 & a & 19 & 15. & 0,50 & $\mathrm{c}$ \\
2 & 19. & 3,00 & a & 20 & 31. & 0,50 & $\mathrm{c}$ \\
3 & 13. & 2,75 & ab & 21 & 7. & 0,25 & $\mathrm{c}$ \\
4 & 26. & 2,25 & abc & 22 & 10. & 0,25 & $\mathrm{c}$ \\
5 & 35. & 2,25 & abc & 23 & 14. & 0,25 & $\mathrm{c}$ \\
6 & 32. & 1,75 & abc & 24 & 28. & 0,25 & $\mathrm{c}$ \\
7 & 34. & 1,75 & abc & 25 & 2. & - & \\
8 & 1. & 1,50 & abc & 26 & 4. & - & \\
9 & 21. & 1,50 & abc & 27 & 5. & - & \\
10 & 27. & 1,50 & abc & 28 & 6. & - & \\
11 & 3. & 1,00 & abc & 29 & 8. & - & \\
12 & 17. & 1,00 & abc & 30 & 9. & - & \\
13 & 30. & 1,00 & abc & 31 & 12. & - & \\
14 & 36. & 1,00 & abc & 32 & 20. & - & \\
15 & 11. & 0,75 & abc & 33 & 22. & - & \\
16 & 18. & 0,75 & abc & 34 & 23. & - & \\
17 & 25. & 0,75 & bc & 35 & 24. & - & \\
18 & 16. & 0,50 & bc & 36 & 29. & - & \\
\hline
\end{tabular}

Hasil pengamatan panjang tunas pada Tabel 4 diperoleh rerata pertumbuhan meninggi tunas klon-klon E. pellita yang diuji berkisar antara 0,17 cm - 17,82 cm. Klon no. 33 dan no. 26 menghasilkan panjang tunas terbaik dengan rerata panjang tunas $17,82 \mathrm{~cm}$ dan 15,63 cm, sedangkan klon no. 15 menunjukkan hasil terendah $(0,17 \mathrm{~cm})$. Sebanyak 12 klon tidak tumbuh tunas sama sekali. Dari hasil analisis varian menunjukan bahwa klon E. pellita berpengaruh signifikan terhadap variasi panjang tunas, sedangkan klon hibrid tidak berpengaruh secara nyata. Adapun hasil pengamatan diameter tunas pada tabel 5 diperoleh rerata diameter tunas dari klon-klon E. pellita yang diuji berkisar antara $0,10 \mathrm{~mm}-2,27$ mm. Klon no. 33 menghasilkan diameter tunas terbaik $(2,27 \mathrm{~mm})$ dan no. 15 terendah $(0,10 \mathrm{~mm})$. Pertumbuhan tunas sambungan dipengaruhi oleh ukuran rootstock yang digunakan dan umumnya rootstock yang berukuran lebih besar menghasilkan pertumbuhan sambungan yang lebih baik (Mng'omba, et al., 2010). Kegiatan pemeliharaan sambungan berupa pembersihan, pemupukan media dan pemangkasan tunas-tunas yang tumbuh pada batang rootstock harus dilakukan secara periodik. 
Vol. 4 No.3, Juli 20I6 (I24-138)

Tabel 4. Rerata panjang tunas dan hasil uji DMRT veneer grafting E. pellita

\begin{tabular}{cccccccc}
\hline $\begin{array}{c}\text { No } \\
\text { urut }\end{array}$ & $\begin{array}{c}\text { Nomor } \\
\text { famili }\end{array}$ & $\begin{array}{c}\text { Penjang } \\
\text { Tunas }(\mathrm{cm})\end{array}$ & DMRT & $\begin{array}{c}\text { No } \\
\text { urut }\end{array}$ & $\begin{array}{c}\text { Nomor } \\
\text { famili }\end{array}$ & $\begin{array}{c}\text { Penjang } \\
\text { Tunas }(\mathrm{cm})\end{array}$ & DMRT \\
\hline 1 & 33. & 17,82 & $\mathrm{a}$ & 19 & 16. & 2,37 & $\mathrm{c}$ \\
2 & 26. & 15,63 & ab & 20 & 30. & 1,95 & $\mathrm{c}$ \\
3 & 35. & 11,73 & abc & 21 & 3. & 1,62 & $\mathrm{c}$ \\
4 & 19. & 10,85 & abc & 22 & 10. & 1,25 & $\mathrm{c}$ \\
5 & 13. & 9,58 & abc & 23 & 14. & 0,28 & $\mathrm{c}$ \\
6 & 27. & 9,18 & abc & 24 & 15. & 0,17 & $\mathrm{c}$ \\
7 & 25. & 8,50 & abc & 25 & 2. & - & \\
8 & 18. & 7,40 & abc & 26 & 4. & - & \\
9 & 32. & 7,33 & abc & 27 & 5. & - & \\
10 & 1. & 7,12 & abc & 28 & 6. & - & \\
11 & 21. & 6,78 & abc & 29 & 8. & - & \\
12 & 34. & 6,25 & abc & 30 & 9. & - & \\
13 & 31. & 4,62 & bc & 31 & 12. & - & \\
14 & 7. & 4,25 & bc & 32 & 20. & - & \\
15 & 36. & 4,25 & bc & 33 & 22. & - & \\
16 & 28. & 3,50 & bc & 34 & 23. & - & \\
17 & 17. & 3,00 & c & 35 & 24. & - & \\
18 & 11. & 2,40 & c & 36 & 29. & - & \\
\hline
\end{tabular}

Tabel 5. Rerata diameter tunas dan hasil uji DMRT veneer grafting E. pellita F. Muell

\begin{tabular}{rcclcccc}
\hline $\begin{array}{l}\text { No. } \\
\text { urut }\end{array}$ & $\begin{array}{c}\text { Nomor } \\
\text { Famili }\end{array}$ & $\begin{array}{c}\text { Diameter } \\
\text { Tunas }(\mathrm{mm})\end{array}$ & DMRT & $\begin{array}{c}\text { No. } \\
\text { urut }\end{array}$ & $\begin{array}{c}\text { Nomor } \\
\text { Famili }\end{array}$ & $\begin{array}{c}\text { Diameter } \\
\text { Tunas }(\mathrm{mm})\end{array}$ & DMRT \\
\hline 1 & 33. & 2,27 & a & 19 & 11. & 0,40 & bcd \\
2 & 26. & 1,60 & ab & 20 & 30. & 0,30 & bcd \\
3 & 19. & 1,53 & abc & 21 & 3. & 0,28 & bcd \\
4 & 35. & 1,53 & abc & 22 & 10. & 0,28 & bcd \\
5 & 27. & 1,10 & abcd & 23 & 14. & 0,13 & cd \\
6 & 34. & 0,98 & abcd & 24 & 15. & 0,10 & cd \\
7 & 13. & 0,97 & abcd & 25 & 2. & - & \\
8 & 32. & 0,95 & abcd & 26 & 4. & - & \\
9 & 18. & 0,93 & abcd & 27 & 5. & - & \\
10 & 1. & 0,88 & abcd & 28 & 6. & - & \\
11 & 21. & 0,82 & bcd & 29 & 8. & - & \\
12 & 25. & 0,72 & bcd & 30 & 9. & - & \\
13 & 28. & 0,57 & bcd & 31 & 12. & - & \\
14 & 31. & 0,57 & bcd & 32 & 20. & - & \\
15 & 7. & 0,50 & bcd & 33 & 22. & - & \\
16 & 16. & 0,50 & bcd & 34 & 23. & - & \\
17 & 36. & 0,50 & bcd & 35 & 24. & - & \\
18 & 17. & 0,42 & bcd & 36 & 29. & - & \\
\hline
\end{tabular}


Terjadinya variasi pertumbuhan tersebut dapat disebabkan oleh faktor genetik maupun lingkungan. Kramer dan Kozlowsky (1979) menyebutkan bahwa pertumbuhan meninggi tanaman lebih banyak dikendalikan oleh faktor genetik. Namun demikian pengamatan dilapangan menunjukan bahwa keberhasilan pertautan sambungan klon-klon E. pellita akan menjadi kunci penting keberhasilan pertumbuhan panjang tunas tersebut. Seperti dijelaskan oleh Ballesta et al., (2010) bahwa pertautan yang baik antara scion dan rootstock merupakan fundamental untuk pertumbuhan sambungan yang optimal, penyerapan air dan translokasi unsur hara pada tanaman tersebut. Pada tahap awal, pertumbuhan semai akan lebih terlihat pada pertumbuhan meningginya, yang ditandai dengan aktifnya pertumbuhan jaringan-jaringan meristematik dari sel-sel kuncup terminal. Hal ini berkaitan dengan adanya dominasi apikal yang dikontrol oleh aktivitas hormon auksin pada bagian kuncup terminal. Dengan demikian umumnya akan terjadi pertumbuhan tinggi yang lebih cepat dibandingkan dengan pertumbuhan diameternya (Wilson, 2000).

\section{KESIMPULAN}

Berdasarkan hasil pengamatan dan analisis beberapa sifat yang diamati pada penyambungan $E$. pellita dengan teknik veneer grafting sampai umur 2 bulan di persemaian, dapat disimpilkan sebagai berikut:

1. Kemampuan tumbuh scion dari pohon plus E. pellita dengan teknik veneer grafting bervariasi antar klon yang ditunjukkan dengan adanya variasi persen hidup sambungan yang nyata.

2. Klon-klon E. pellita menunjukkan respon pertumbuhan yang bervariasi secara nyata pada karakter jumlah tunas, panjang tunas dan diameter tunasnya. 
Vol. 4 No.3, Juli 20I6 (124-138)

\section{UCAPAN TERIMA KASIH}

Penulis mengucapkan terima kasih kepada Balai Besar Penelitian Bioteknologi dan Pemuliaan Tanaman Hutan sebagai institusi tempat pelaksanaan penelitian ini. Selain itu penulis mengucapkan terima kasih kepada Saudara Didik Indriatmoko, Bapak Gatot Lanjar dan Saudara Suwandi yang telah banyak membantu pelaksanaan penelitian ini sejak pengambilan scion di KBSUK Wonogiri dan pembibitan di persemaian. 


\section{DAFTAR PUSTAKA}

Adinugraha, H.A. dan Sunarti, S. 2004. Pengaruh Naungan dan Asal Scion Terhadap Keberhasilan Sambungan Jenis Eucalyptus. Jurnal Penelitian Hutan Tanaman Vol. 1 No. 1, halaman 13-20.

Adinugraha, H.A., Pudjiono, S. dan Yudistiro, D. 2007. Pertumbuhan Stek Pucuk Dari Tunas Hasil Pemangkasan Semai Jenis Eucalyptus pellita F. Muell di Persemaian. Jurnal Penelitian Hutan Tanaman Vol. 1 No. 1, halaman 43-49.

Ballesta, M.C.M., Lopez, C.A., Muries, B., Cadenas, C.M. and Carvajal, M. 2010. Physiological aspects of rootstock-scion interactions. Scientia Horticulturae 127(2010): 112-118.

Cholid, M., Hariyadi., Susanto, S., Djumali and Purwoko, BS. 2014. Effect of grafting time and grafting methods used on scion and rootstock compatibililty of physic nut (Jatropha curcas). Asian Journal of Agriculture Research 8(3): 150-163.

Dickinson, G.R. 2011. The Future of Tropical Hardwood Tree Improvement: Greater Cooperation. Guest Editorial. Journal of Tropical Forest Science 23(3) : 229-231

Dombro, D.B. 2010. Eucalyptus pellita: Amazonia Reforestation's red mahogany. Planeta Verde Reforestacion S.A.

Frey, H.H., Frampton, J., Blazich, F.A., Hundley, D. and Hinesley, E. 2011. Graftingf Fraser Fir (Abies fraseri): Effect of scion origin (crown position and branch order). HortScience 46 (1): 91-94.

Herdyantara, A.B. 2010. Pengembangan Klon Eucalyptus pellita di Aara Abadi. Prosiding Ekspose Hasil-hasil penelitian. Status Terkini Penelitian Pemuliaan Tanaman Hutan di Yogyakarta 1 Oktober 2009, halaman 85-95.

Khan, M. 1995. Proceedings National Course on Tree Improvement and Propagation. Pakistan Forest Institute 22-26 February 1994. FAO Los Banos, Phillipines

Korkutal, I., Kaygusuz, G. and Bayram, S. 2011. Different effect of scion types on callusing in bench grafting. African Journal of Biotechnoilogy Vol. 10 (67). Pp. 15123-15129

Kramer and Kozlowaki. 1979. Physiology of Woody Plants. Academic Press. New York. London.

Kumar, G.N.M. 2011. Propagation of Plants by Grafting and Budding. A Pasific Northwest Extension Publication. PNW 496. 18 p.

Kulkarni, H.D. 2002. Bhadrachalam Clones of Eucalyptus- an Achievement of ITC. IUFRO Science/Policy Interface Task Force Regional Meeting held in Chennai, India, 16-19 July 2002.

Lavender, D.P. 1984. Plant Physiology and Nursery Environment: Interactions Affecting Seedling Growth. Pp 133-141

Leksono, B. 2001. Potensi Eucalyptus pellita F Muell untuk Pembangunan Hutan Tanaman Industri (HTI) dan Program Pemuliaan Pohon. Makalah Simposium Nasional dan Kongres IV PERIPI. Pusat Pebnelitian dan Pengembangan Bioteknologi dan Pemuliaan Tanaman Hutan. Yogyakarta. 
Leksono, B., dan Setyaji, T. 2004. Variasi Petumbuhan Tinggi dan Diameter Pada Uji Keturunan Eucalyptus pellita Sistem Populasi Tunggal. Jurnal Penelitian Hutan Tanaman Vol 1, No. 2, halamalan 67-78.

Leksono, B. dan setyaji, T. 2010. Lima Belas Tahun Pemuliaan Eucalyptus pellita: Hasilhasil yang telah dicapai. Prosiding Ekspose Hasil-hasil penelitian. Status Terkini Penelitian Pemuliaan Tanaman Hutan di Yogyakarta 1 Oktober 2009, halaman 8595.

Mng'omba, SA., Akinnifesi, FK., Sileshi, G. and Ajayi, OC. 2010. Rootstock growth and development for increase graft success of mango (Mangifera indica) in the nursery. African Journal of Biotechnology Vol 9 (9), pp. 1317-1324.

Moko, H., Adinugraha, H.A., dan Chigira, O. 2001. Penelitain Pendahuluan Pengaruh Penyimpanan Scion Terhadap Keberhasilan sambungan Pada Eucalyptus pellita. Buletin Penelitian Pemuliaan Pohon Vol 5 (1): 11-20.

Orwa, C., Mutua, A., Kindit, R., Jamnadass R., and Anthony, S. 2009. Agroforestree Database: a tree reference and selection guide version 4.0

Proenza, Y.G., Alvarez R.Q., Tamayo, Y.V., Saavedra, M.A., Garcia, Y.S. and Espinosa, R.H. 2013. Chemical composition and antibacterial activity of the essential oil from Eucalyptus pellita F. Muell. Journal of Medicinal Plant Research vol. 7(27) pp. 1979-1983.

Abo-rehab, MEA., Kora, AKM., Kambawi, MAM., and Yousef KYA. 2013. Fungal species associated with graft union on Grapevine its impact on graft failure process and attempted solution in Egypt. International Journal of Agriculture and Forestry 3(2): 52-59.

Sachs, RM., Lee, C., Ripenda, J. and Woodward, R. 1988. Selection and clonal propagation of eucalyptus. California Agriculture. Pp. 27-31.

Siahaan, L.A. 2010. Studi terhadap penyakit daun tanaman Eukaliptus di kebun percobaan PT. Toba pulp Lestari sektor Aek Nauli. Jurusan Budidaya Hutan, Fakultas Kehutanan Universitas Sumatera Utara Medan.. Di download dari http://repository.usu.ac.id/ tanggal 15 Desember 2014.

Satrosupadi, A. 2000. Rancangan Percobaan Praktis Bidang Pertanian. Edisi Revisi. Kanisius. Yogyakarta.

Sunarti, S. 2012. Variasi Pertumbuhan Tinggi Pada Uji Klon Eucalyptus pellita F. Muell di Wonogiri, Jawa Tengah. Jurnal Penelitian Pemuliaan Tanaman Hutan Vol. 6 No. 1, halaman 57-63.

Wilson, B.F. 2000. Apical control of branch growth and angle inwoody plants. American Journal of Botany 87(5): 601-607. 
Vol. 4 No.3, Juli 20I6 (124-138)

Lampiran 1. Informasi pohon induk tanaman Eucaliptus pellita sebagai bahan uji

\begin{tabular}{|c|c|c|c|c|c|c|c|c|}
\hline $\begin{array}{l}\text { No. } \\
\text { Seri }\end{array}$ & No. Famili & $\begin{array}{l}\text { No. } \\
\text { Seedlot }\end{array}$ & $\begin{array}{l}\text { No. } \\
\text { Individu }\end{array}$ & Pro & Negara & Lat. & Long & Alt \\
\hline 1. & $28-18-75$ & 18197 & CG18191 & S of Kiriwo WP & PNG & 8.25 & 141.30 & 45 \\
\hline 2. & $27-11-85$ & 18198 & BVG2156 & $\mathrm{N}$ of Kiriwo WP & PNG & 8.20 & 141.32 & 45 \\
\hline 3. & $28-13-26$ & 17875 & GCM1029 & Tozers GAP & AUS & 12.44 & & 100 \\
\hline 4. & $23-23-91$ & 18198 & BVG2150 & $\mathrm{N}$ of Kiriwo WP & PNG & 8.20 & 141.32 & 45 \\
\hline 5. & $24-23-144$ & 18197 & CG1889 & S of Kiriwo WP & PNG & 8.25 & 141.30 & 45 \\
\hline 6. & $25-23-44$ & 18197 & BVG2141 & S of Kiriwo WP & PNG & 8.25 & 141.30 & 45 \\
\hline 7. & $26-20-66$ & 18197 & CG1882 & S of Kiriwo WP & PNG & 8.25 & 141.30 & 45 \\
\hline 8. & 24-18-155 & 18200 & BVG2214 & Keru to Nata WP & PNG & 8.36 & 141.45 & 130 \\
\hline 9. & $22-19-54$ & 18197 & CG1870 & S of Kiriwo WP & PNG & 8.25 & 141.30 & 45 \\
\hline 10. & $23-19-10$ & 17854 & MM1294 & Bupul-Muting & IND & 7.21 & 140.36 & 40 \\
\hline 11. & $24-19-43$ & 18197 & $\mathrm{BVC}$ & & & 8.25 & & 45 \\
\hline 12. & 26-14-34 & 17875 & JSL1 & Toz & JS & 12.44 & 143.12 & 100 \\
\hline 13. & $25-14-2$ & 18197 & $\mathrm{BVC}$ & $\mathrm{WP}$ & PNG & 8.25 & 141.30 & 45 \\
\hline 14. & $10-8-2$ & 18197 & CG1 & WP & PNG & 8.25 & 141.30 & 45 \\
\hline 15. & $20-12-50$ & 18197 & CG1 & S of Kir & PNG & 8.25 & 141.30 & 45 \\
\hline 16. & $25-63-2$ & 18197 & CG1879 & S of Kir & $\mathrm{NG}$ & 8.25 & 141.30 & 45 \\
\hline 17. & $10-7-134$ & 18199 & CG1907 & Serisa Village WP & PNG & 8.36 & 141.26 & 45 \\
\hline 18. & $4-7-136$ & 18199 & CG1909 & Serisa Village WP & PNG & 8.36 & 141.26 & 45 \\
\hline 19. & $15-4-154$ & 00 & $\mathrm{BV}$ & ( & PNG & 8.36 & & 130 \\
\hline 20. & $22-3$ & & & & & 8.36 & & 45 \\
\hline 21. & $24-14-73$ & & & WP & $\mathrm{NG}$ & 8.25 & .30 & 45 \\
\hline 22. & $35-8-104$ & & BV & WP & PNG & 8.20 & 141.32 & 45 \\
\hline 23. & $22-25-138$ & 199 & CG1 & ge WP & PNG & 8.36 & 141.26 & 45 \\
\hline 24. & $29-2-62$ & 197 & CG1 & S of Kiriwo WP & PNG & 8.25 & 141.30 & 45 \\
\hline 25. & $26-19-3$ & 197 & CG1 & vo WP & PNG & 8.25 & 141.30 & 45 \\
\hline 26. & $31-15-151$ & 3200 & BVG2210 & Keru to Nata WP & PNG & 8.36 & 141.45 & 130 \\
\hline 27. & $37-8-96$ & 18198 & BVG2166 & Kiriwo WP & PNG & 8.20 & 141.32 & 45 \\
\hline 28. & $20-7-105$ & & & & & 8.20 & 141.32 & 45 \\
\hline 29. & $37-1$ & & & & & 8. & & 130 \\
\hline 30. & $29-15-89$ & & $\mathrm{BVC}$ & WP & $\mathrm{NG}$ & 8.20 & & 45 \\
\hline 31. & $26-5-123$ & 99 & $\mathrm{BVC}$ & WP & PNG & 8.36 & 141.26 & 45 \\
\hline 32. & $25-28-142$ & 199 & CG1 & a Village WP & PNG & 8.36 & 141.26 & 45 \\
\hline 33. & $33-7-14$ & 17854 & MM1298 & Bupul-Muting & IND & 7.21 & 140.36 & 40 \\
\hline 34. & $41-3-121$ & 18199 & BVG2197 & Village WP & PNG & 8.36 & 141.26 & 45 \\
\hline 35. & $22-7-83$ & 198 & BVG2154 & $\mathrm{N}$ of Kiriwo WP & PNG & 8.20 & 141.32 & 45 \\
\hline 36. & $22-6-55$ & 97 & CG1871 & WP & PNG & 8.25 & 141.30 & 45 \\
\hline $\mathrm{H} 1$ & $25-25-89$ & & & & & 8.20 & & 45 \\
\hline $\mathrm{H} 2$ & $9-8-1$ & & $\mathrm{BVC}$ & $\mathrm{K}$ & NG & 8.36 & .45 & 130 \\
\hline $\mathrm{H} 3$ & $9-7-155$ & 18200 & BVG2214 & Keru to Nata WP & PNG & 8.36 & 141.45 & 130 \\
\hline $\mathrm{H} 4$ & $5-8-155$ & 18200 & BVG2214 & Keru to Nata WP & PNG & 8.36 & 141.45 & 130 \\
\hline H5 & $30-18-136$ & 18199 & CG1909 & Serisa Village WP & PNG & 8.36 & 141.26 & 45 \\
\hline H6 & $21-9-131$ & 18199 & CG1903 & Serisa Village WP & PNG & 8.36 & 141.26 & 45 \\
\hline
\end{tabular}

